\title{
Nursing undergraduate education in relation to the death-dying process: perceptionsin light of the complex thinking
}

\author{
Formação do enfermeiro em relação ao processo de morte-morrer: \\ percepções à luz do pensamento complexo \\ Formación del enfermero con relación al proceso de muerte-morir: \\ percepciones a la luz del pensamiento complejo
}

\author{
Matheus Viero Dias ${ }^{\mathrm{a}}$ \\ Dirce Stein Backes ${ }^{b}$ \\ Edison Luiz Devos Barlem ${ }^{c}$ \\ Marli Terezinha Stein Backes ${ }^{d}$ \\ Valéria Lerch Lunardie \\ Martha Helena Teixeira de Souza ${ }^{f}$
}

DOl: $\quad$ http://dx.doi.org/10.1590/19831447.2014.04.45177

\footnotetext{
a Nurse. Master in Nursing. Doctoral student of the Nursing Postgraduate Program of the School of Nursing, Federal University of Rio Grande (PPGEnf/FURG).

${ }^{b}$ Nurse. PhD in Nursing. Professor at Centro Universitário Franciscano - Santa Maria.

c Nurse. PhD in Nursing. Professor at PPGEnf/FURG.

${ }^{d}$ Nurse. PhD in Nursing. Professor at Federal University of Santa Catarina.

e Nurse. PhD in Nursing. Professor at PPGEnf/FuRG Scholar of Research Productivity from the National Council for Scientific and Technological Development (CNPq, as per its acronym in Portuguese).

${ }^{f}$ Nurse. PhD in Nursing. Professor at Centro Universitário Franciscano - Santa Maria.
}

\section{ABSTRACT}

The objective of this study was to perceive the death-dying process from the perspective of nursing students. This is an exploratory, descriptive and qualitative research study. Data were collected between June and July 2013, from three focus groups with six nursing students at a University Center located in the central region of Rio Grande do Sul, Brazil. The meetings were organized with an approach to increase discussions about the death-dying process from the perspective of the complex thinking. Data were analyzed by means of the Strategic Focal Analysis, and three categories were created: Death: a process of rupture or continuity?; Recognizing weaknesses in the undergraduate educational process; and Outlining strategies to broaden academic discussions. It is possible to conclude that the death/dying process is minimally discussed in undergraduate courses, and when it is discussed, it happens in a fragmented and disjunctive manner, without integrating it into the human living process.

Descriptors: Death. Education, nursing. Attitude to death.

\section{RESUMO}

Objetivou-se conhecer a percepção do processo de morte-morrer na perspectiva de discentes de enfermagem. Pesquisa exploratório- descritiva de caráter qualitativo, cujos dados foram coletados entre junho e julho de 2013, a partir de três encontros focais, com seis discentes de enfermagem de um Centro Universitário Comunitário localizado na região central do Rio Grande do Sul. Os encontros foram organizados/dinamizados de modo que ampliassem as discussões acerca do processo morte-morrer na perspectiva do pensamento complexo. A partir da Análise Focal Estratégica dos dados, foram delimitadas três categorias: Morte: processo de ruptura ou continuidade?; Reconhecendo fragilidades no processo de formação e Delineando estratégias capazes de ampliar as discussões acadêmicas. Conclui-se que o processo de morte-morrer é minimamente discutido na formação profissional do enfermeiro e, quando discutido, os debates ocorrem de forma fragmentada e disjuntiva, não integrando-0 ao processo de viver humano.

Descritores: Morte. Educação em enfermagem. Atitude frente à morte.

\section{RESUMEN}

Se tiene por objetivo conocer la percepción del proceso de muerte-morir en la perspectiva de discentes de enfermería. Investigaciones exploratorias y descriptivas de carácter cualitativo, cuyos datos fueron recolectados entre junio y julio de 2013, a partir de tres encuentros focales con seis discentes de enfermería de un Centro Universitario localizado en la región central do Rio Grande do Sul, Brasil. Los encuentros fueron organizados/dinamizados de modo que ampliasen las discusiones acerca del proceso muerte-morir en la investigación del pensamiento complejo. Del Análisis Focal Estratégico de los datos, fueron delimitadas tres categorías: Muerte: ¿proceso de ruptura o continuidad?; Reconociendo fragilidades en el proceso de formación y Delineando estrategias capaces de ampliar las discusiones académicas. Se concluye que el proceso de muerte-morir es mínimamente discutido en la formación profesional del enfermero, y cuando discutido, los debates ocurren de forma fragmentada y disyuntiva, no integrándolo al proceso del vivir humano. Descriptores: Muerte. Educación en enfermería. Actitud frente a la muerte. 


\section{DINTRODUCTION}

The nursing undergraduate program, which is based on curricular guidelines, is aimed at educating generalist critical-reflective professionals, focused on different settings and on themes that address human life. Therefore, it must be founded on broad non-fragmented approaches, which will result in an attentive look at all dimensions that involve human beings, including death.

The curricula of undergraduate nursing courses usually emphasize the importance of care in maintaining life and issues related to its end are commonly sidelined ${ }^{(1)}$. In this context, nursing students graduate, not often, thinking strictly on maintaining and saving lives. From a complex point of view, which allows for the perception of the extent of phenomena, this does not invalidate the need to know how to deal with death(2).

One of the greatest barriers for nursing students as for dealing with the death-dying process may result from the fact that the meaning of this phenomenon for human beings is not broadly discussed and thought about throughout the course ${ }^{(3)}$. Likewise, this also happens with the meaning of life.

Death and the death-dying process are complex, uncertain and singular phenomena. Therefore, it is the duty of undergraduate nursing courses to provide appropriate conditions to students so they can broaden their perception, as well as reflections and meanings including the life dynamics.

The uncertainties regarding the matter are not just gaps in the knowledge of students, as they can and must be considered and understood as possibilities that favor the development of intelligence in the scope of complexity ${ }^{(4)}$. Thus, complexity exists when different elements are inseparable components of a whole $e^{(5)}$.

Complex thinking is responsible for broadening knowledge and takes into account all internal and external influences $^{(6)}$. In this case, it is possible to carry out a reflection on the death-dying process as part of the life cycle $e^{(7)}$.

It is important to discuss about references that may broaden the thinking, both of nursing professors and students. The references considered, thus, comprehend the complexity as well as the multi-dimensionality of human life, seeing death not only as a one-off event. Thus, these discussions should be dealt with in the same way as birth-human development are discussed(8).

Based on the aforementioned, and considering that this topic is poorly discussed during the nurses' education, the following question emerged: how do nursing students perceive the death-dying process? The objec- tive was to understand nursing students' perceptions about the death-dying process. In order to expand and discuss the process from other approaches, the complex thoughts of Edgar Morin were used as a guide, as they propose interconnections and new perceptions about the phenomena that are involved in the death-dying process, which explains the importance of this study.

\section{$\square$ METHOD}

Exploratory, descriptive and qualitative study, carried out in a Community University Center in the central area of the state of Rio Grande do Sul, Brazil, with six undergraduate nursing students from the 6th, 7th and 8th semesters. Two students from each semester were selected according to their registration number.

Students from these periods were chosen because they are in the end of the course and they have already experienced most course specialties. Students who were not comfortable with discussing the topic were excluded. However, all selected participants were in favor of participating in the study.

For data collection, the Focus Group (FG) technique was chosen, which favors broad and horizontal problematization of the topic and/or specific focus ${ }^{(9)}$. Three meetings were held between June and July 2013, up to two hours long, coordinated by a moderator, with the presence of all students. The meetings were guided by specific topics, including the study theme and the objective. At the first meeting, the study proposal was presented, doubts were clarified and the Free and Informed Consent Form was signed.

For each meeting, an initial group dynamics was conducted, allowing for the integration among participants and the formulation of ideas. Likewise, meetings were closed with a short collective analysis/synthesis, giving way to the following discussions. At the first meeting, each participant presented his/her individual perceptions about the death-dying process, which was followed by a collective debate. At the end, a guiding text related to complex thinking, by Edgar Morin, was handed over for individual reading. This text aimed to place the death-dying process in the logic of complex thinking, broadening perceptions for the next meeting collective debate.

The second FG was conducted in such a way that reflections about the death-dying process were made from a wide and complex point of view, thus adding more content to it. The problematization and broadening of collec- 
tive perceptions continued, based on previously available material. At the third FG, the synthesis of previous meetings was resumed and the researchers tried to outline strategies that could broaden academic discussions around the death/dying process with a complex thinking approach. At the end of discussions, a general synthesis of the meetings was made.

The Strategic Focal Analysis (SFA) was used as a data analysis technique, once it includes the complexity and design of strategies, which expands understanding of the death/dying process. The SFA appears as an appropriate analytical possibility for $\mathrm{FG}$, with emphasis on the insertion of participants as active subjects in the process of data collection, analysis and synthesis, which begin simultaneously with data collection ${ }^{(9)}$.

The FGs had the following logic: SFA of the strengths and weaknesses related to the investigated phenomenon, as well as the analysis of opportunities and challenges ${ }^{(9)}$ related to the death-dying process.

The research was initiated after the approval of the Health Research Ethics Committee of the Federal University of Rio Grande, (number 105/2013), in compliance with the requirements of Resolution 196/96 of the National Research Ethics Committee of the Ministry of Health. Anonymity of the participants was ensured and they were identified by the acronym " $\mathrm{Di}$ " followed by a Roman number, in ascending order, which corresponded to the participants' speeches. For instance: "Di. I", "Di. II", and so on, until the total number of participants was reached.

\section{RESULTS AND DISCUSSION}

Based on the broad and complex collection, synthesis and analysis of data, both collective and individually, three categories were later defined by the researchers, as follows.

\section{Death: a process of rupture or continuity?}

Questioned about the meaning of death and/or the death-dying process, the students gave different ideas, among which the understanding of death as part of the human life cycle stands out. For the participants, death is not acknowledged as a fragmented phenomenon, of rupture or that dissociates from life, but rather as an event that is inherent to the life process.

Nursing students need to arm themselves with knowledge to be able to deal with this topic, as a complex knowledge of death will be acquired by means of a deeper understanding of life. To discuss death in light of complexity means to further the topic, as death is the greatest total human phenomenon(6). Thus, a broad perception of the factors that form the process is needed, in a horizontal/ complex manner.

It is worth highlighting that the death-dying process is an inherent step of the life cycle, which closes a period of existence. Therefore, it is a collective and individual representation, and for many, death is considered the end of the world $(1,4)$. In that sense, there is not a single concept of death. When symbolizing and including it in their ideas and thoughts, each individual will try to metaphorize it their own way ${ }^{(10)}$ :

[...] I started to understand that death becomes just a cycle, a common process like being born, and you will only be able to discuss, argue or talk to a patient about a sensitive matter if you have arguments. This will depend on your ability to deal with uncertainties and insecurities. (Di. IV)

For the nursing student to acquire broad and complex knowledge, it is essential that the training process goes beyond specific and biological considerations of death, leading to a non-reductionist reflections. In some cases, the attempt to conceal the acknowledgment of death, fragmenting it as a rupture of life, is the same as ignoring its relationship with the life dynamics, although it means the end of it ${ }^{(11)}$.

In this context, and according to the statements of some participants, the death-dying process can be compared to a cocoon, acting like a protection. In other words, human beings use defense mechanisms to try and escape the apparent disorder provoked by the death-dying process.

Students need to become sensitive to the care provided to those who experience/follow this process. The lack of discussion about this topic during undergraduate studies contributes to the development of this protective mechanism, making it difficult to provide greater nursing care, which suggests understanding death as an event that is part of the life cycle.

In this context, the incentive for thanatology research under a complex approach will leverage greater understanding concerning care strategies, thus reinforcing the idea that complexity is not only an empirical phenomenon ${ }^{(1,12)}$.

I came up with the outline of death, as if it were a cocoon. When we begin to talk about death, it looks like a terrible thing. We begin to get into this cocoon [..]. We are still a 
bit reluctant to talk about it, to talk about death and these phases we go through [...]. (Di. III)

[...] we brought this discussion to the classroom. [...] because this topic is uncertain, not safe, because it has never been worked on. I think this death issue, just like other topics that are related to uncertainty, brings disorder [...] (Di. IV)

These statements suggest that the topic should be addressed with nursing students as a process of continuity of the life cycle, rather than a disruption. It is possible to notice that regardless of their stage in the course, students have converging ideas and reflections. For some participants, particularly for those who experienced complex references, the meaning of death already reaches an understanding of comprehensiveness and continuity. In this context, all precious things become fragile, rare and face an uncertain future. Therefore, when new islands of certainties are found and kept, one must bear in mind that he is sailing in an ocean of uncertainties ${ }^{(13)}$.

\section{Recognizing weaknesses in the undergraduate educational process}

Addressing this death issue during the nursing undergraduate education is not an easy task. This process activates brain mechanisms, giving rise to feelings/references of life, as it is necessary to accept the fact that existence itself, as well as of people with whom we keep interpersonal relationships, have an unknown "expiration date" ${ }^{\prime \prime(14)}$.

It is worth highlighting the need to further theoretical knowledge in order to increase the possibilities of interaction and understanding the finite nature of the process, without causing any disruption. Therefore, it is necessary to go further into references that allow for the understanding and acknowledgment of complex phenomena involved in the death-dying process ${ }^{(5)}$. Thus, death itself is also part of the human development process and is present in the daily lives of nursing professionals, from the moment they graduate $^{(15-16)}$.

This topic is minimally addressed during practical classes, and it is done superficially and in a fragmented way in theoretical discussions, far from the daily reality ${ }^{(1)}$.

In the participants'speeches, the need to address the matter in a systematic/broaden manner throughout the nursing education was evident. Further discussions and reflections are essential, and they need to be intrinsically addressed in all courses. It possible to notice that the interviewees try not only to talk about the topic, but also debate/reflect in a complex way, so as to reach its full understanding:

Why do we talk so naturally about so many things and are afraid to talk about death? I bring this up, to the university, because we talk too little about this (Di. V)

To get rid of this vision, I believe that this issue should be discussed throughout the course, not only in two or three disciplines (Di. II)

From a complex point of view, death can/must be understood as a natural and universal process, inherent to life ${ }^{(11,17-18)}$. In this sense, care services require sensitivity, devotion, empathy, a watchful eye, sharpened and not fragmented perception, interaction and knowledge in order to deal with uncertainties and face them ${ }^{(10)}$.

This idea is in line with another study ${ }^{(10)}$ that reports the difficulty of nursing students to comfort and embrace families after the loss of a loved one, that is, they state they do not know how to act in face of death/grief, as a result of their lack of preparation. The aforementioned study confirms the findings of our study; however, a broader look, based on complex thinking, appears to be a differential to (re)think this process:

As a nursing student, I see that we cannot treat it as something fragmented. [...] So in our practice, we have to think: "Are we ready to deal with that patient and those relatives?" [...] I think this topic is discussed, but not indepth! (Di. I)

Just look at how we're all afraid, regardless of our years of profession, to tell them "well, your relative did not resist". This has never been worked on, [...] and I think that we are here to change that (Di.V)

It is increasingly believed that the function of the nursing education is to train and transform thinking subjects, as well as to provide conditions to students to experience the care practice and face the dying process ${ }^{(2)}$. Despite the fact that death is perceived as part of the life cycle, it is possible to observe that nursing students are not prepared enough to provide comprehensive and horizontal care, at all dimensions of human life, as far as the death-dying process is concerned ${ }^{(3)}$. Moreover, the interviewed students themselves admit this frailty and propose significant changes in the educational process. 


\section{Outlining strategies to broaden academic discussions}

The death/dying process has been often understood and worked on in a linear manner during the nursing education, as previously mentioned. From this point of view, death represents a contradictory event to life, causing fear, suffering, uncertainties and frustration, to the detriment of a multi-factor approach, guided by biological, cultural and psychosocial aspects, which have a direct and indirect influence on the actions and emotions of all subjects ${ }^{(4,19)}$.

When providing a greater care, that is, being able to perceive the complexity of the process, nursing students have to perceive themselves as active subjects in the decision of breaking away with practice fragmentation and have a multi-dimensional look ${ }^{(20)}$. This care is understood as a complex phenomenon, that is, capable of going beyond the specific and linear understanding of the death-dying process. Thus, discussions about the importance of the relationship between contents need to be reflected/broaden, without encouraging fragmented knowledge from a simplified understanding, but rather promoting the construction of a uniform and complex knowledge, in a joint vision, made up of different dimensions that are part of the life dynamics(6)

In order to understand death in a way that it does not bring emotional suffering, it is necessary that future professionals be duly supplied with information during academic training to have a complex understanding of the phenomenon ${ }^{(2)}$. To do so, nursing professors and institutions must take on the role of providing spaces for debate and broad reflections, and review the paradigm in place that sees death as a rupture of life, as reported by some participants:

When there was a death in the ICU, it was as if everybody was ready, and the professor was with us. She came and explained what was going to happen, so we were not surprised, it seemed natural to us. (Di. VI)

There is not a formula, but you can think about it, reflect. (Di. V)

It's not about being ready, but knowing how to deal with it. (Di. III)

It is not possible to understand complexity as a formula or an answer to frailties related to death. It is necessary to consider it as a challenge, a motivating phenomenon to think about the death-dying process as part of the life cycle and rather than a rupture. Complexity is translated into the articulation of conceptions, whereas simplifying thoughts separate different aspects or join them through a mutilating reduction ${ }^{(12)}$

Complexity as a theoretical strategy to favor the extension of academic discussions regarding death allows for the integration of antagonistic and apparently contradictory processes ${ }^{(13)}$. Therefore, nursing care needs to be borne and discussed from references that allow integrating and putting into context different elements that are part of the human life cycle, as we can notice in the following statements:

When you experience this, you look at it differently. [...] There is a long way to go, by training professors and interacting with students. (Di. II)

It's all too fragmented and we cannot expect that students treat it in an isolated manner, at the moment of practice or even after their degree; the subject is isolated somewhere, and when someone asks about it, they have to retrieve it. They know what death is, but they can't answer about death, because it was worked in an isolated fashion. [...] But I think that the adequate strategy is theoretical foundation, because you think in an open and broad manner, in a context, so death is no longer considered as an illness. (Di. I)

I think this issue should be addressed in the classroom, in practice, in research, so it is valued. [...] There is no need for a formula or a readymade answer, just give it its importance, promote a debate. [...] So this is the big challenge of education, contribute to this [...] when teaching is fragmented, when work is fragmented. (Di. IV)

Fragmentation/reduction of actions and knowledge, as it was perceived by participants and as it commonly happens in nursing undergraduate education, is a way of fractioning social issues, turning multi-dimensional aspects into one-dimensional ones, besides making knowledge increasingly simple regarding the death-dying process ${ }^{(6,13)}$. Therefore, the discussion about death alone will not enable its full understanding/acceptance.

It is necessary to discuss the phenomenon as part of the life cycle, not as an end. This topic should be discussed and broaden throughout the nursing education, so future professionals feel they have a support to deal with this issue in their daily routine. 


\section{口CONCLUSION}

Based on the observations of this study, it is possible to conclude that nursing courses offer a generalist, critical and reflective approach but address the death-dying process, as well as other topics, in a fragmented and specific manner. Superficiality and trivialization of the discussion around this process do not allow broadening the understanding of this phenomenon, as death is considered by most participants as the end of life, and not as part of the life cycle.

Death is part of the nursing practice routine. Therefore, it is necessary to consider it and include it in theoretical and practical discussions, since the theme is complex and requires equally complex thoughts. In this case, the interviewees themselves admit the need to broaden discussions and reflections about the topic in specific places and in all disciplines involved in nursing courses.

Then, group discussions and the foundation on references that understand death as a part of the living process are seen as strategies to problematize this matter throughout education, both in theory and in practice. Therefore, it is necessary to go beyond simplifying knowledge, which reduces and fragments, to reach the type of reflection that broadens, integrates and promotes circularity of different events of life.

In conclusion, the death-dying process is minimally discussed in professional education, and when it is discussed, debates take place in a fragmented and disjunctive manner, with minor improvements in broadening and integrating it into the process of human life. It is also important to highlight the lack of studies that address complex thinking in the context of the death-dying process, especially in the educational process. Therefore, this study has a broad, horizontal and complex feature, which is necessary so as not to fragment social and natural events. Innovative theoretical and practical strategies are suggested, which can contribute to broaden and contextualize the nursing care at the different stages integrating the life cycle.

\section{DEFERENCES}

1. Lima MGR, Nietsche EA, Teixeira JA. Reflexos da formação acadêmica na percepção do morrer e da morte por enfermeiros. Rev. Eletr. Enf. [Internet]. 2012 [citado 2013 Jan 11];14(1):181-8. Disponível em: http://www.fen.ufg.br/ fen_revista/v14/n1/pdf/v14n1a21.pdf

2. Oliveira WIA, Amorin RC. A morte e o morrer no processo de formação do enfermeiro. Rev Gaúcha Enferm. [Internet]. 2008 [citado 2013 Jan. 17];29(2):1918. Disponível em: http://seer.ufrgs.br/RevistaGauchadeEnfermagem/article/ view/5580
3. Mota MS, Gomes GC, Coelho MF, Lunardi Filho WD, Souza LD. Reações e sentimentos de profissionais da enfermagem frente à morte dos pacientes sob seus cuidados. Rev Gaúcha Enferm. [Internet]. 2011 [citado 2012 Dez 20];32(1):129-35. Disponível em: http://seer.ufrgs.br/RevistaGauchadeEnfermagem/article/view/16326

4. Morin E. 0 método Il: a vida da vida. Porto Alegre: Sulina; 2005.

5. Morin E. Os sete saberes necessários à educação do futuro. 2. ed. rev. São Paulo: Cortez: Brasília, DF: UNESCO; 2011.

6. Petraglia I. Edgar Morin: a educação e a complexidade do ser e do saber. 11. ed. Petrópolis, RJ: Vozes; 2010.

7. Dias MV. Processo de morte-morrer à luz do pensamento complexo: percepções de docentes e discentes de enfermagem [dissertação]. Rio Grande: Universidade Federal do Rio Grande; 2013.

8. Oliveira SG, Quintana AM, Bertolino KCO. Reflexões acerca da morte: um desafio para a enfermagem. Rev Bras Enferm. [Internet]. 2010 [citado 2013 Jan. 13];63(6):1077-80. Disponível em: http://www.scielo.br/scielo. php?pid=S0034-71672010000600033\&script=sci_arttext

9. Backes DS, Colomé JS, Erdmann RH, Lunardi VL. Grupo focal como técnica de coleta e análise de dados em pesquisas qualitativas. 0 mundo da saúde. [Internet]. 2011 [citado 2012 Dez 03];35(4):438-42. Disponível em: http://bvsms. saude.gov.br/bvs/artigos/grupo_focal_como_tecnica_coleta_analise_dados_pesquisa_qualitativa.pdf

10. Cantídio FS, Vieira MA, Sena RR. Significado da morte e de morrer para os alunos de enfermagem. Invest Educ Enferm. [Internet]. 2011 [citado 2013 Jan 22];29(3):407-18. Disponível em: http://www.scielo.org.co/scielo. php?pid=S0120-53072011000300009\&script=sci_arttext

11. Oliveira SG, Quintana AM, Budó MLD, Lüdtke MF, Cassel PA, Wottrich SH, et al. Significados de morte e morrer no curso de enfermagem: um relato de experiência. Rev Enferm UFSM [Internet]. 2012 [citado 2012 Dez 03];2(2):472-79. Disponível em: http://cascavel.ufsm.br/revistas/ojs-2.2.2/index.php/reufsm/ article/view/3493

12. Morin E. Ciência com consciência. Ed. revista e modificada pelo autor. 14a ed. Rio de Janeiro: Bertrand Brasil; 2010.

13. Morin E. A cabeça bem-feita: repensar a reforma, reformar o pensamento. 19. ed. Rio de Janeiro: Bertrand Brasil; 2011.

14. Silva KS, Ribeiro RG, Kruse MHL. Discursos de enfermeiras sobre morte e morrer: vontade ou verdade? Rev Bras Enferm. [Internet]. 2009 [citado 2012 Dez 20];62(3):451-6. Disponível em: http://www.scielo.br/scielo.php?pid=S0034$-71672009000300019 \&$ script=sci_arttext

15. Combinato DS, Queiroz MS. Um estudo sobre a morte: uma análise a partir do método explicativo de Vigotski. Ciência \& Saúde Coletiva [Internet]. 2011 [citado 2013 Jan 11];16(9): 3893-900. Disponível em: http://www.scielo.br/scielo. php?script=sci_arttext\&pid=\$1413-81232011001000025

16. Ribeiro DB, Fortes RC. Morte e o morrer na perspectiva de estudantes de enfermagem. Revisa [Internet]. 2012 [citado 2012 Dez 10];1(1):32-9. Disponível em: http://revistafacesa.senaaires.com.br/index.php/revisa/article/view/10

17. Lima MGR, Nietsche EA, Santos SC, Teixeira JA, Bottega JC, Nicola GDO, et al. Revisão integrativa: um retrato da morte e suas implicações no ensino acadêmico. Rev Gaúcha Enferm. [Internet]. 2012 [citado 2013 Jan 17];33(3):190-7. Disponível em: http://www.scielo.br/scielo.php?pid=\$1983$-14472012000300025 \&$ script=sci_arttext

18. Araújo TC, Silva RS, Pereira A. 0 cuidado sensível ao paciente sob cuidados paliativos. In: Silva RS, Amaral JB, Malagutti W, organizadores. Enfermagem em cuidados paliativos: cuidando para uma boa morte. São Paulo: Martinari „2013. p. $139-48$. 
19. Edo-Gual M, Tomás-Sábado J, Aradilla-Herrero A. Miedo a la muerte en estudiantes de enfermería. Enferm Clin. [Internet]. 2011 [citado 2012 Dez 10];21(3):12935. Disponible en: http://www.elsevier.es/es/revistas/enfermeria-clinica-35/ miedo-muerte-estudiantes-enfermeria-90020578-originales-2011
20. Poveda MAM, Amaral JB. Ritos e crenças perante a morte e a prática de cuidar. In: Silva RS, Amaral JB, Malagutti W, organizadores. Enfermagem em cuidados paliativos: cuidando para uma boa morte. São Paulo: Martinari;2013. p. 49-58.

\section{Author's address:}

Matheus Viero Dias

Rua Vinte e Quatro de Maio, 264/05, Centro

96200-003, Rio Grande, RS.

E-mail: enf.matheusviero@gmail.com
Received: 20.02.2014

Approved: 24.10.2014 